\title{
ATTEMPTS TO SEPARATE RABBIT SPERMATOZOA BY MEANS OF FROTH FLOTATION AND THE SEX RATIO OF OFFSPRING BORN*
}

\author{
G. J. MORE O'FERRALL, $\dagger$ T. N. MEAGHAM AND \\ W. E. FOREMAN \\ Departments of Animal Science and Mining Engineering, \\ Virginia Polytechnic Institute, Blacksburg, Virginia 24061, U.S.A.
}

(Received 6th fuly 1967)

\begin{abstract}
Summary. New Zealand White does were inseminated with spermatozoa, separated into two fractions (float and sink) by means of froth flotation, in an attempt to control the sex ratio of their offspring. Seventy-eight litters-twenty-six control, twenty-seven float and twenty-five sink--were produced by twenty-seven does and seven bucks during an 8-month period (August to March). The control, float and sink litters contained $57 \cdot 1,51 \cdot 1$ and $52 \cdot 6 \%$ males, respectively, indicating that the flotation technique was unsuccessful in separating spermatozoa, on the basis of their sex determining ability. Average litter size and conception rate were significantly increased $(P<0.01)$ when does were induced to ovulate by a hormone injection (HCG or LH) $2 \mathrm{hr}$ before, rather than at the time of, insemination. Repeated injections of HGG did not adversely affect subsequent conception.
\end{abstract}

\section{INTRODUCTION}

Attempts by man to control the sex of his own and his animals' progeny have so far been unsuccessful. Recent experiments in which a sedimentation technique was used to separate male-determining or Y-bearing spermatozoa and femaledetermining or X-bearing spermatozoa, yielded promising results. Using sedimentation, Bhattacharya (1962) obtained $72 \%$ female offspring and $77 \%$ male offspring when he inseminated does with heavy and light rabbit spermatozoa, respectively. A later attempt to produce similar results in cattle was unsuccessful (Bhattacharya, Bangham, Gro, Keynes \& Rowson, 1966). Inseminating with heavy bull spermatozoa, Schilling (1966) obtained 70\% female calves.

Experiments in which electrophoresis was used to separate rabbit spermatozoa (Schroder, 1934; Gordon, 1957), seemed to indicate that male- and female-determining spermatozoa carried different electrical charges. Vesselinovitch (1959) was unable to separate spermatozoa by means of micro-electrophoresis, but when macro-electrophoresis was used bull spermatozoa were

* Published with approval of the Director, Agricultural and Life Sciences.

$\dagger$ Present address: The Agricultural Institute, Dunsinea, Castleknock, Co. Dublin, Ireland. 
recovered from both the anodic and cathodic parts of the macrocell. Subsequent insemination of these fractions of bull spermatozoa failed to alter the sex ratio of calves born (Macpherson \& Vesselinovitch, 1959). Nevo, Michaeli \& Schindler (1961) have shown that all bull and rabbit spermatozoa carry negative surface charges.

These conflicting reports led us to hypothesize that perhaps there were differences in the surface chemistry of spermatozoa dependent on the sex chromosome carried by the spermatozoon. As froth flotation is used to separate minerals on the basis of their surface differences and has recently been used successfully to separate micro-organisms (Gaudin, 1962), it was thought that this technique might also be used to separate rabbit spermatozoa.

The present study was undertaken: (a) to see if froth flotation could be used to separate successfully rabbit spermatozoa; and (b) if a separation were obtained, to determine by insemination whether this separation was due to differences in the sex determining ability of the spermatozoa. Observations on the effect of the time of an ovulatory hormone injection in relation to the time of insemination are also included in this report.

\section{MATERIALS AND METHODS}

A total of thirty-three does and seven bucks of the New Zealand White breed was used in this study. The majority of the does (twenty-four) were purchased at sexual maturity from a local breeder, while three does of varying parity were on hand. The remaining six does were obtained from the University breeding unit as replacements for six of the twenty-four purchased does which had not produced a litter following four inseminations. All animals were caged individually for at least 3 weeks before first breeding and were fed a restricted amount $(4 \mathrm{oz})$ of pelleted feed daily.

Semen was collected from the males by means of an artificial vagina, using a teaser female. The bucks were sexually stimulated by use of a false mount whereby they were allowed to mount the female and make a series of pelvic thrusts without intromission; they were then allowed or forced to dismount. Following ejaculation the semen volume was recorded and the semen was examined under the microscope and scored for motility. Spermatozoa concentration was determined using a haemocytometer and the $\mathrm{pH}$ was recorded with a Beckman zeromatic $\mathrm{pH}$ meter.

If a semen sample was considered suitable for insemination, it was diluted 1:10 with Ringer's solution ( $\mathrm{pH}=8 \cdot 1$ ) of the following composition: $0.900 \%$ $\mathrm{NaCl}, 0.040 \% \mathrm{KCl}, 0.025 \% \mathrm{CaCl}_{2}, 0.020 \% \mathrm{NaHPCO}_{3}, 0.001 \% \mathrm{NaHPO}_{4}$ and distilled water, of which the conductivity was $2 \times 10^{-6} \mu$-mohs $/ \mathrm{ml}$. One-third of the diluted semen was kept for control inseminations, while the remaining twothirds was separated by means of flotation.

\section{Flotation process}

The set-up of the flotation apparatus is shown in Plate 1. The flotation cell is a Buchner funnel with a porous fritted glass base (Plate 1, A). This funnel is connected to a flowmeter (Plate 1, B), which is joined to a Teflon monostat 


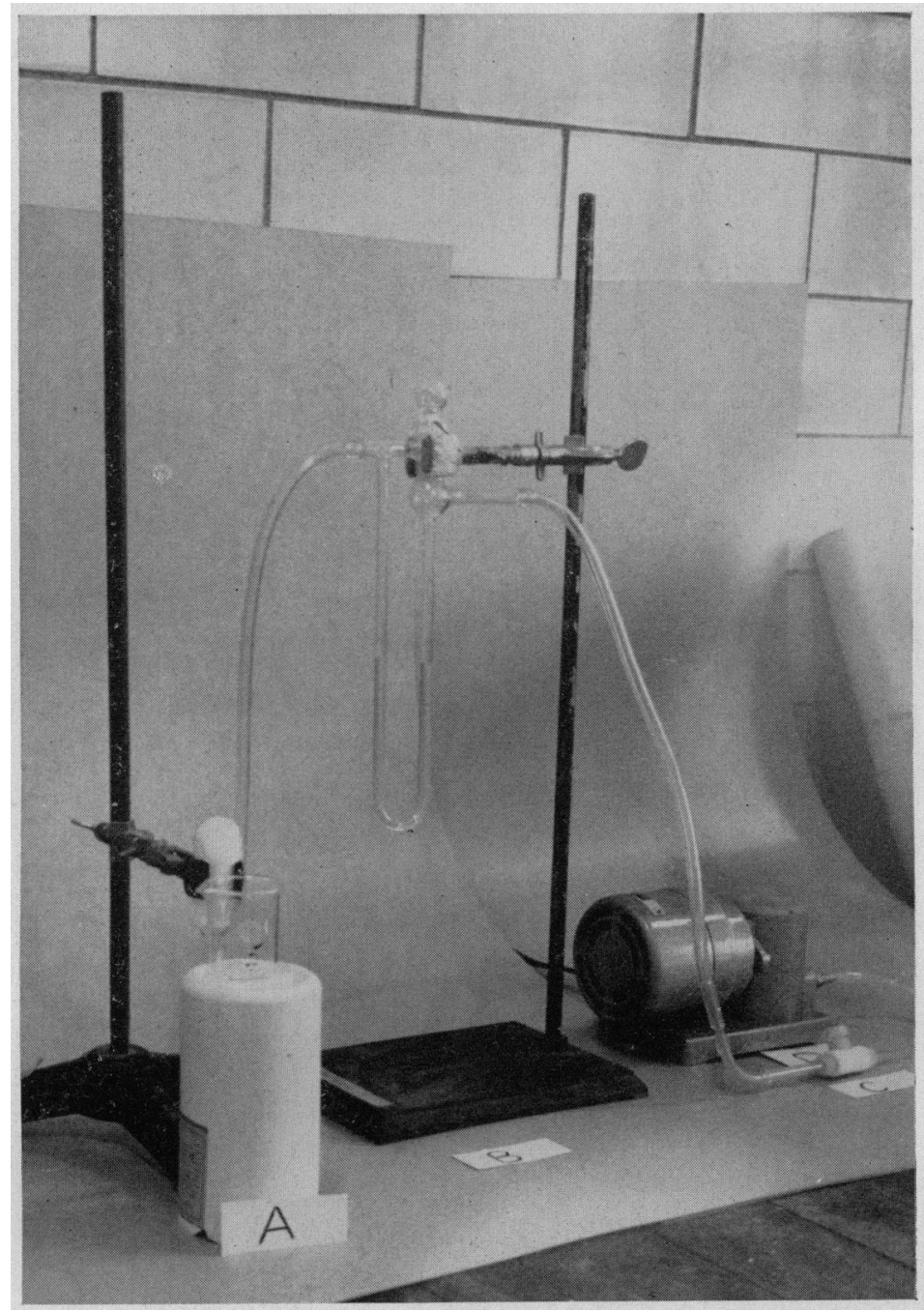

Flotation system of separation. A, Flotation cell showing flotation froth; B, fowmeter for standardization of air flow; $\mathrm{C}$, Tefion monostat needle valve; $\mathrm{D}$, pressure-vacuum pump. 
needle valve (Plate $1, \mathrm{C}$ ) and thence to a small pressure-vacuum dyno pump (Plate 1, D). The flowmeter consists of a U-tube, on which a hollow $\overrightarrow{\$}$ stopper with four orifices is mounted in such a way that the $0.25-\mathrm{mm}$ orifice is used. The U-tube is half-filled with water and the air flow regulated by means of the needle valve so that there is a difference of $3.5 \mathrm{~cm}$ between the two heads. This difference is used to standardize the air flow from one experiment to the next. The air flow rate through the system is 0.233 litre/min.

Following standardization of the air flow the pump was switched off and the diluted semen was poured into the flotation cell; the pump was then switched on and the air allowed to bubble through the semen. At first, the air bubbles with spermatozoa attached are small and frothy in appearance (Plate 1, A), but as the flotation proceeds the bubbles become larger and gradually clear; when this occurs, the air supply is cut down by adjusting the needle valve and the flotation is considered complete. The whole process takes less than 2 min to run. The fraction that comes over (containing the froth) is termed the float fraction, while that remaining in the cell is termed the sink.

It was observed that the percentage of spermatozoa obtained in the float fraction varied somewhat depending on the $\mathrm{pH}$ of the diluted semen (More O'Ferrall, 1967). When the $\mathrm{pH}$ was $7 \cdot 0$, approximately $69 \%$ of the spermatozoa were contained in the float fraction, while at a $\mathrm{pH}$ of 8.5 the proportion of spermatozoa in the float dropped to approximately $48 \%$. Following the first four experiments the $\mathrm{pH}$ of the diluted semen was adjusted to $\mathrm{pH} 7.9$ to 8.0 before flotation by the addition of a few drops of a $1 \%$ citric acid or a $1 \%$ sodium hydroxide solution, as needed.

Altogether, eight experiments or series of inseminations were carried out, but the procedure during the flotation process for different groups of experiments was varied somewhat as follows:

Experiments 1 to 3 . The flotation procedure was similar to that described above. The diluted semen varied from $\mathrm{pH} 7 \cdot 5$ to $8 \cdot 1$ due to differences in raw semen $\mathrm{pH}$ from different bucks.

Experiments 4 to 6 . As the results of the first three experiments were not very promising, it was decided, in this group of experiments, to collect approximately the first half of the froth, designated top float (TF), for insemination from the float fraction. The flotation was then continued beyond the normal end-point and this middle fraction was discarded; the spermatozoa remaining in the flotation cell, designated bottom sink (Bs), were used for sink inseminations. In Exp. 5, semen from two or more bucks was pooled in order to give greater volume for flotation.

Experiments 7 and 8 . As the results from the first six experiments indicated that the flotation process was not successful in separating the two types of spermatozoa, it was decided to treat the semen somewhat differently before flotation.

Following evaluation of the semen, it was diluted 1:15 with Ringer's solution. Two-thirds of the diluted semen was then centrifuged at $500 \mathrm{rev} / \mathrm{min}$ for $8 \mathrm{~min}$ in order to concentrate the spermatozoa in the bottom of the centrifuge tube. 
The seminal plasma was then pipetted off into another centrifuge tube and centrifuged at $1000 \mathrm{rev} / \mathrm{min}$ for $10 \mathrm{~min}$ in order to remove most of the remaining spermatozoa, which were discarded. The concentrated spermatozoa were rediluted with $8 \mathrm{ml}$ Ringer's solution and the flotation then carried out as in the earlier experiments. The two fractions recovered (wF and ws-refer to Table 1) were again centrifuged at $500 \mathrm{rev} / \mathrm{min}$ for $5 \mathrm{~min}$, the supernatant Ringer's solution was pipetted off and the spermatozoa were then mixed with the centrifuged seminal plasma. Their motility was again checked and a spermatozoa count was made before insemination.

\section{Experimental design and artificial insemination}

In each experiment, the does were randomly divided into breeding groups of equal size. Within each group the does were further randomly assigned to the three insemination groups-control (c), float $(\mathbf{F})$ and sink (s); any extra does were allotted to the float or sink in preference to the control group.

Ovulation was induced in the does by the intravenous injection of 35 i.u. of human chorionic gonadotrophin (Gonamone, Fort Dodge Laboratories) in the first six experiments and by the injection of $0.035 \mathrm{mg}$ of luteinizing hormone (Bovine PLH, National Institutes of Health) in Exps. 7 and 8. In Exp. 5, a random half of the does was injected $2 \mathrm{hr}$ before insemination and the remainder injected at the time of insemination. In the last three experiments all does were injected $2 \mathrm{hr}$ before insemination. Insemination was made by means of a glass pipette, a minimum of $6 \times 10^{6}$ spermatozoa being inseminated into each doe, although generally at least $10 \times 10^{6}$ spermatozoa were inseminated. One female from each group was inseminated in turn to guard against deterioration of any one group of spermatozoa.

Does were palpated to determine pregnancy 10 to 12 days following insemination and if twelve or more does were diagnosed non-pregnant, these were inseminated again within 18 to 21 days of the previous insemination. The remaining does were allowed to go to term. The young were removed from the mother as soon as possible after kindling and the number born was recorded. The young were then chloroformed and their sex determined externally by extrusion of the genital organs and then internally by examination of the gonads. In some instances the does destroyed young at birth; where possible these were counted in the litter size but they could not be sexed in many cases. All does kindling were re-inseminated 12 to 14 days following parturition in the first five experiments. In the last three experiments, however, does were inseminated again within 7 days of parturition, as Hammond \& Marshall (1925) observed that all does are in oestrus for this period and if inseminated again they will generally become pregnant.

Chi-square analyses $\left(\chi^{2}\right)$ were used to test for differences in the sex ratio of the insemination groups, the expected numbers in the float and sink groups being determined by the sex ratio obtained in the control litters. The possibility of interaction between the sex ratio from each male and between the sex ratio in each experiment was tested for by contingency chi-square within each insemination group. Differences in conception rate were also tested by chi-square, while the ' $t$ '-test was used to test for differences in mean litter size. 


\section{RESULTS}

A total of seventy-eight litters was produced from 177 inseminations by twentyseven female and seven male rabbits during an 8-month period, August to March. No female produced more than four litters during this period. The litter size ranged from one to fourteen with an overall mean of $5 \cdot 3 \pm 0 \cdot 31$. No difference was found in the sex ratio of litters sired by different males so that the data were pooled, according to the flotation procedure used, within each insemination group. These pooled data for conception rate, sex ratio and mean litter size are given in the upper part of Table 1. The sex ratio of litters born

\section{TABLE 1}

CONCEPTION RATE, NUMBER OF RABBITS BORN, SEX RATIO AND AVERAGE LITTER SIZE FOR DIFFERENT GROUPS OF EXPERIMENTS AND FOR ALL EXPERIMENTS BY SPERM FRACTION INSEMINATED

\begin{tabular}{|c|c|c|c|c|c|c|c|c|}
\hline \multirow{2}{*}{ Experiments } & \multirow{2}{*}{$\begin{array}{c}\text { Sperm } \\
\text { fraction* }\end{array}$} & \multirow{2}{*}{$\begin{array}{c}\text { No. does } \\
\text { inseminated }\end{array}$} & \multirow{2}{*}{$\begin{array}{c}\text { No. } \\
\text { preg- } \\
\text { nancies }\end{array}$} & \multirow{2}{*}{$\begin{array}{l}\text { Conception } \\
\text { rate }(\%)\end{array}$} & \multirow{2}{*}{$\begin{array}{c}\text { Total } \\
\text { young } \\
\text { born }\end{array}$} & \multicolumn{2}{|c|}{ Sex ratio } & \multirow{2}{*}{$\begin{array}{c}\text { Litter size } \\
\text { (Mean士 } \\
\text { S.E. })\end{array}$} \\
\hline & & & & & & $M: F \dagger$ & $\%$ Males & \\
\hline 1 to 3 & $\begin{array}{l}\mathbf{G} \\
\mathbf{F} \\
\mathbf{S}\end{array}$ & $\begin{array}{l}19 \\
22 \\
23 \\
64\end{array}$ & $\begin{array}{r}5 \\
8 \\
8 \\
21\end{array}$ & $\begin{array}{l}26 \cdot 3 \\
36 \cdot 4 \\
34 \cdot 8 \\
32 \cdot 8\end{array}$ & $\begin{array}{r}17 \\
51 \\
34 \\
112\end{array}$ & $\begin{array}{c}9: 7 \\
22: 26 \\
14: 13\end{array}$ & $\begin{array}{l}56 \cdot 3 \\
45 \cdot 8 \\
51 \cdot 9\end{array}$ & $\begin{array}{l}3.4 \pm 0.60 \\
6.4 \pm 0.94 \\
4.3 \pm 0.92 \\
5.3 \pm 0.57\end{array}$ \\
\hline 4 to 6 & $\begin{array}{l}\text { G } \\
\text { TF } \\
\text { BS }\end{array}$ & $\begin{array}{l}24 \\
27 \\
26 \\
77\end{array}$ & $\begin{array}{l}11 \\
12 \\
11 \\
34\end{array}$ & $\begin{array}{l}45 \cdot 8 \\
44 \cdot 4 \\
42 \cdot 3 \\
44 \cdot 2\end{array}$ & $\begin{array}{r}56 \\
51 \\
69 \\
176\end{array}$ & $\begin{array}{l}29: 22 \\
28: 23 \\
33: 36\end{array}$ & $\begin{array}{l}56 \cdot 9 \\
54 \cdot 9 \\
47 \cdot 8\end{array}$ & $\begin{array}{l}5.1 \pm 0.72 \\
4.3 \pm 0.72 \\
6.3 \pm 0.82 \\
5 \cdot 2 \pm 0.44\end{array}$ \\
\hline 7 to 8 & $\begin{array}{l}\text { G } \\
\text { WF } \\
\text { WS }\end{array}$ & $\begin{array}{l}12 \\
13 \\
11 \\
36\end{array}$ & $\begin{array}{r}10 \\
7 \\
6 \\
23\end{array}$ & $\begin{array}{l}83 \cdot 3 \\
53 \cdot 8 \\
54 \cdot 5 \\
63 \cdot 9 * *\end{array}$ & $\begin{array}{r}53 \\
42 \\
43 \\
138\end{array}$ & $\begin{array}{l}30: 22 \\
21: 19 \\
25: 16\end{array}$ & $\begin{array}{l}57 \cdot 7 \\
52 \cdot 5 \\
61 \cdot 0\end{array}$ & $\begin{array}{l}5 \cdot 3 \pm 0.78 \\
6.0 \pm 0.98 \\
7.2 \pm 1.64 \\
6.0 \pm 0.61\end{array}$ \\
\hline $\begin{array}{l}\text { Total } \\
\text { of all } \\
\text { experiments }\end{array}$ & $\begin{array}{l}\mathbf{C} \\
\mathbf{F} \\
\mathbf{S}\end{array}$ & $\begin{array}{r}55 \\
62 \\
60 \\
177\end{array}$ & $\begin{array}{l}26 \\
27 \\
25 \\
78\end{array}$ & $\begin{array}{l}47 \cdot 3 \\
43 \cdot 5 \\
41 \cdot 7 \\
44 \cdot 1\end{array}$ & $\begin{array}{l}126 \\
144 \\
146 \\
416\end{array}$ & $\begin{array}{l}68: 51 \\
71: 68 \\
72: 65\end{array}$ & $\begin{array}{l}57 \cdot 1 \\
51 \cdot 1 \\
52 \cdot 6\end{array}$ & $\begin{array}{l}4.8 \pm 0.45 \\
5.3 \pm 0.51 \\
5.8 \pm 0.63 \\
5.3 \pm 0.31\end{array}$ \\
\hline
\end{tabular}

* $\mathrm{G}=$ control, $\mathrm{F}=$ float, $\mathrm{TF}=$ top float, $\mathrm{WF}=$ washed float, $\mathrm{S}=\operatorname{sink}, \mathrm{BS}=\mathrm{bottom} \operatorname{sink}$, WS $=$ washed sink.

$\dagger$ Discrepancies between these figures and those in the previous column indicate that the additional young could not be sexed due to cannibalism by the mother.

** $P<0.01$ compared to Experiments 1 to 3 .

in different experiments or groups of experiments, within each insemination group, was also found not to differ, so these data were pooled over all experiments and are given in the lower part of Table 1 . The overall sex ratio of the control group did not differ significantly from a 50:50 ratio $\left(\chi_{(1)}^{2}=2 \cdot 48,0 \cdot 10<P\right.$ $<0.20$ ), while that of the float and sink groups did not differ from the controls (float, $\chi_{(1)}^{2}=2 \cdot 07,0 \cdot 10<P<0 \cdot 20$; sink, $\chi_{(1)}^{2}=1 \cdot 18,0 \cdot 20<P<0 \cdot 30$ ), or from one another. There was no significant difference in litter size among the insemination groups, although that from the sink group was somewhat larger. Similarly, no significant difference in conception rate among the groups was 


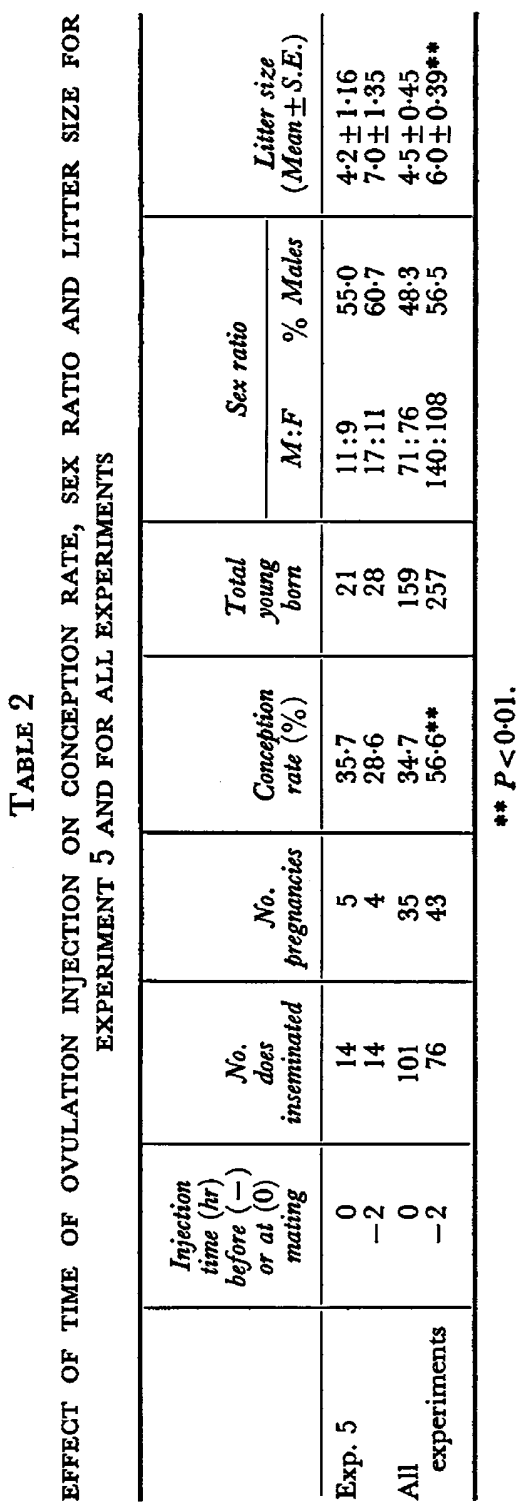


found. The conception rate did increase significantly $(P<0-01)$ in the last group of experiments compared to Exps. 1 to 3.

The time of the ovulatory injection in relation to insemination had a sig nificant effect on conception rate and litter size as shown in the lower part of Table 2. The injection $2 \mathrm{hr}$ before insemination significantly increased both traits $(P<0.01)$. The sex ratio was also higher in the earlier injected group, although the difference was not significant. The results from Exp. 5 (Table 2) show no difference in conception rate or sex ratio for the different injection times and, while the difference in litter size did not reach significance due to the small number of litters involved, it was sufficient for us to decide to inject all does in subsequent experiments $2 \mathrm{hr}$ before insemination.

The percentage fertility of the different males, calculated as the ratio of litters born to females inseminated, and the mean size of these litters are given in Table 3. There was considerable variation in the fertility of the different males

TABLE 3

FERTILITY OF AND AVERAGE LITTER SIZE BY DIFFER

\begin{tabular}{c|c|c|c|c}
\hline Male No. & $\begin{array}{c}\text { No. } \\
\text { does } \\
\text { inseminated }\end{array}$ & $\begin{array}{c}\text { No. } \\
\text { litters } \\
\text { born }\end{array}$ & $\begin{array}{c}\text { Fertility } \\
(\%)\end{array}$ & $\begin{array}{c}\text { Total No. } \\
\text { young born }\end{array}$ \\
\cline { 2 - 4 } & 20 & 4 & $20 \cdot 0$ & 20 \\
3 & 24 & 10 & $41 \cdot 7$ & 49 \\
4 & 34 & 8 & $23 \cdot 5$ & 38 \\
6 & 36 & 29 & $80 \cdot 6$ & 169 \\
57 & 12 & 4 & $25 \cdot 0$ & 14 \\
59 & 9 & 4 & $44 \cdot 4$ & 15 \\
81 & 14 & 10 & $71 \cdot 4$ & 62 \\
Mixed semen & 28 & 9 & $32 \cdot 1$ & 49 \\
Total & 177 & 78 & $44 \cdot 1$ & 416 \\
\hline
\end{tabular}

Litter size
(MeantS.E.)

$5-0+2-12$

$4-9+0-74$

$4-8+1-26$

$5-8 \pm 0-53$

3-5+0-87

$3-8 \pm 0-75$

$6-2+0-47$

$5-4+0-96$

$5-3+0-31$

although this did not seem to be closely related to mean litter size. It was originally decided to use all males equally, but the conception rate was so low in the earlier experiments that only the more fertile maes were used to sire litters in the last two experiments.

\section{DISCUSSION}

The lack of difference in sex ratio, among the three insemination groups, observed in these experiments seems to indicate that froth flotation is not a successful method for separating spermatozoa on the basis of their sex-determining ability. Thus, the hypothesis, that the $\mathrm{X}$ and $\mathrm{Y}$ sex chronosomes give rise to differences in the surface chemistry of the two types of spermatozoa, is open to doubt. The results obtained by Schroder (1934) and Gordon (1957), following the insemination of electrophoretically separated rabbit spermatozoa, seemed to Indicate that the two types ot spermatozioa had surtace differences. However, the explanation, given by Nevo et al. (1961), that these results could not be due to an electrophoretic separation of oppositely charged cells but was probably due to galvanotaxis, seems more likely correct. Flotation was successful in effecting a separation, which seems to indicate that some spermatozoa do have 
surface differences. However, the fact that the proportion of spermatozoa in either fraction could be varied by altering the $\mathrm{pH}$ of the diluted semen further indicates that these differences are not determined by the sex chromosome carried by the spermatozoon.

The sex ratio of $57.1 \%$ in the controls was somewhat higher than expected. Baier \& Haeger (1958) obtained a sex ratio of $55.2 \%$ in artificially inseminated cows, which was considerably higher than the $51.5 \%$ obtained by Johansson (1932) under conditions of natural mating. The sex ratio of the controls varied very little from one group of experiments to another, but that of the float and sink groups fluctuated considerably. However, as no consistent trend was found, either from litters within any one experiment or from one experiment to the next, it seems that this fluctuation was merely a chance effect.

The flotation procedure did not apparently adversely affect the fertilizing ability of the spermatozoa. There was little difference in the conception rates of the three insemination groups, although the controls had a slightly higher rate with $47.3 \%$. The sink fraction, while it gave the lowest conception rate, resulted in litters with an average of one young more per litter than the controls.

The overall conception rate of $44.1 \%$ and the mean litter size of 5.3 were both low in comparison to the $68 \%$ conception and 7.4 young per litter obtained by Sittmann, Rollins, Sittmann \& Casady (1964) under conditions of natural mating in California. Adams (1961) found the results of artificial insemination to compare very favourably with those obtained with natural mating. The fact that the conception rate reached $64 \%$ in the last group of experiments as compared to $33 \%$ in the first group would seem to indicate that this might be a seasonal effect, although the use of the more fertile males in these experiments could also be responsible for this increase. The first group of experiments were carried out in the autumn months and the latter ones in the spring, and, while rabbits kept under laboratory conditions do not normally undergo an anoestrous period, these periods coincide with the end and beginning, respectively, of the breeding season of wild rabbits. Sittmann et al. (1964) also found conception rates to be lower in autumn months. The significant difference in conception rate found between the times of the ovulatory injection (Table 2) can possibly be explained on the same basis. The fact that no difference in conception rate was obtained between the two groups in Exp. 5 would seem to support the fact that it is a seasonal effect.

Expected difficulties, arising from repeated use of the same hormone (HCG) to induce ovulation, were not encountered. During the 5-month period covered by the first six experiments, the majority of the does were injected five times. Of nineteen does injected with HCG for the fifth time in Exp. 6, thirteen produced litters, giving a conception rate of over $68 \%$. Adams (1961) found that following repeated LH injections the percentage of does conceiving dropped sharply. Of twenty-four does injected for a fifth time over a period of $8 \frac{1}{2}$ months only $13 \%$ conceived. When these twenty-four were split into equal groups and half were given a sixth injection and the other half naturally mated, the conception rates were 0 and $100 \%$, respectively. Adams (1961) attributed their failure to become pregnant to ovulation failure due to antibody formation in response to repeated treatment with exogenous $\mathbf{L}$. 
The highly significant differences in mean litter size between the times of hormone injection was somewhat unexpected in view of previously published results. It is generally accepted that the rabbit will ovulate approximately 10 $\mathrm{hr}$ following stimulation. It has been estimated that spermatozoa take from 2 to $5 \mathrm{hr}$ to reach the site of fertilization in the rabbit (Braden, 1953; Adams, 1956), while they must spend at least $6 \mathrm{hr}$ in the female genital tract before they become capacitated and ready for fertilization (Chang, 1951). Generally, it is ageing of the ova rather than spermatozoa that causes a decline in fertilization. Hammond (1934) estimated that ova were only capable of fertilization for up to $6 \mathrm{hr}$ following ovulation. Chang (1952) observed that they were capable of fertilization up to $8 \mathrm{hr}$ after ovulation, but that fertilizability dropped sharply after $4 \mathrm{hr}$.

Assuming, then, that it takes $6 \mathrm{hr}$ for capacitation, the spermatozoa in the present experiment would be ready for fertilization 2 to $4 \mathrm{hr}$ before the ova were ovulated (depending on the time of injection) and thus there would be no question of ageing of ova but rather the spermatozoa would be ageing somewhat. Dziuk (1965) indicated that, while a certain minimum period of $6 \mathrm{hr}$ may be required for maturation of spermatozoa in the female genital tract, maturation continues for at least an extra $4 \mathrm{hr}$ which imparts an advantage over less mature spermatozoa. These conflicting results suggest that the question of interval between ovulation and insemination and its effect on litter size, in relation to ageing of spermatozoa, should be investigated further.

The $8 \%$ difference in sex ratio in favour of the earlier injected group, though not statistically significant, is interesting in relation to the theory (later refuted by VanDemark \& Malven, 1960) that, in cows, insemination early in heat would give more female offspring and later in heat more male offspring. This means that later inseminations would bring the time of spermatozoa capacitation and ovulation closer together as cows ovulate $36 \mathrm{hr}$ after the beginning of oestrus or 12 to $14 \mathrm{hr}$ after going out of heat. The effect of the earlier injection in the present study would be similar. This might indicate that male-determining spermatozoa lose their ability to fertilize ova more quickly following capacitation or conversely that female-determining spermatozoa require a longer time in the female genital tract before being capable of fertilization.

\section{ACKNOWLEDGMENTS}

The authors wish to thank the National Institutes of Health for supplying the bovine PLH, and Dr D. F. Watson for supplying the replacement rabbits. Financial assistance given to one of us (G.J.M.O'F.) by the Director of the Agricultural Institute, Dublin, is gratefully acknowledged.

\section{REFERENCES}

Adams, C. E. (1956) A study of fertilization in the rabbit: the effect of post-coital ligation of the Fallopian tube or uterine horn. 7. Endocr. 13, 296.

Adams, C. E. (1961) Artificial insemination in the rabbit. J. Reprod. Fert. 2, 521.

Baier, W. \& HaEger, O. (1958) Über das Geschlechtsverhaltnis der Nackommen aus der kunstlichen Besamung. Tierarztl. Wochenschr. 71, 426.

Bhattacharya, B. GH. (1962) Die verschiedene Sedimentations-geschwindigkeit der X- und YSpermien und die Frage der willkurlichen Geschlechtsbestimmung. Z. wiss. Zool. 166, 203. 
Bhattacharya, B. Gh., Bangham, A. D., Cro, R. J., Keynes, R. D. \& Rowson, L. E. A. (1966) An attempt to predetermine the sex of calves by artificial insemination with spermatozoa separated by sedimentation. Nature, Lond. 211, 863.

Braden, A. W. H. (1953) Distribution of sperms in the genital tract of the female rabbit after coitus. Aust. F. biol. Sci. 6, 693.

Chanc, M. C. (1951) Fertilizing capacity of spermatozoa deposited in the fallopian tubes. Nature, Lond. $168,697$.

Chang, M. C. (1952) Fertilizability of rabbit ova and the effects of temperature in vitro on their subsequent fertilization and activation in vivo. F. exp. Zool. 121, 35.

Dzıuk, P. J. (1965) Double mating of rabbits to determine capacitation time. F. Reprod. Fert. 10, 389.

Gaudin, A. M. (1962) Flotation of microorganisms. In: Froth Flotation-50th Anniv. Vol., p. 658. Ed. D. W. Fuerstenau. Amer. Inst. Min. Metall. and Pet. Engrs., Inc., New York.

Gordon, M. J. (1957) Control of sex ratio in rabbits by electrophoresis of spermatozoa. Proc. nat. Acad. Sci. U.S.A. 43, 913.

Hammond, J. (1934) The fertilization of rabbit ova in relation to time. A method of controlling litter size, the duration of pregnancy, and the weight of the young at birth. F. exp. Biol. 11, 140.

Hammond, J. \& Marshall, F. H. A. (1925) Reproduction in the rabbit. Oliver \& Boyd, London.

Johansson, I. (1932) The sex ratio and multiple births in cattle. Z. Tierzücht. ZüchtBiol. 24, 165.

Macpherson, J. W. \& Vesselinovitch, S. D. (1959) Electrophoresis of bovine semen. IV. Sex ratio in cattle resulting from electrophoretically treated semen. Canad. 7. comp. Med. 23, 375.

More O'Ferrall, G. J. (1967) Flotation as a means of artificially controlling the distribution of the sexes in rabbits. Ph.D. thesis, Virginia Polytechnic Institute, Blacksburg, Virginia, U.S.A.

Nevo, A. C. Mrchaeli, I. \& Schinder, H. (1961) Electrophoretic properties of bull and rabbit spermatozoa. Expl Cell Res. 23, 69.

Schilling, E. (1966) Experiments in sedimentation and centrifugation of bull spermatozoa and the sex ratio of born calves. 7. Reprod. Fert. 11, 469.

Schroder, V. N. (1934) Physico-chemical analysis in some questions of the physiology of spermatozoa. V. Artificial control of sex in mammals. (Translated title). Biol. Zh. 3, 465. (Anim. Br. Abstr. 3, 166.)

Sittmann, D. B., Rollins, W. C., Sittmann, K. \& Casady, R. B. (1964) Seasonal variation in reproductive traits of New Zealand White rabbits. F. Reprod. Fert. 8, 29.

VanDemark, N. L. \& Malven, P. V. (1960) Do A.I. practices affect the sex ratio? A.I. Dig. 8, 11.

Vesselinovitch, S. D. (1959) Microelectrophoresis of bovine spermatozoa. Cornell Vet. 49, 359. 